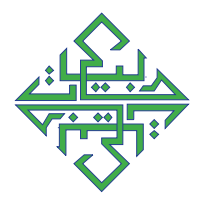

\title{
POLICY IMPLEMENTATION OF THE SABILILLAH SPECTACULAR STAGE (SSS) PROGRAM TO INCREASE STUDENTS' SPEAKING SKILLS
}

\author{
Mamnunah, Syihabuddin, Yayan Nurbayan \\ Universitas Pendidikan Indonesia, Bandung, Indonesia \\ Jl. Dr. Setiabudi No. 229, Kota Bandung, Jawa Barat, 40154, Indonesia \\ Corresponding E-mail:mamnunab96@upi.edu
}

\begin{abstract}
One of the factors that support and influence students' fluency in Arabic communication is the presence of a language-learning environment (bi'ah lughawiyah). This study aimed to describe how Pesantren Sabilillah implemented the policies in the Sabilillah Spectacular Stage program in improving Maharatul Kalam and how the program improved students' speaking skills (maharah al-kalam). This study used a qualitative approach. The data were obtained from interviews, observations, and documentation. Participants included the boarding school caretakers, the Arabic language program coordinator, asatidz, and ustadzat, and all students living in the boarding school dormitory. This study's results indicate that the Spectacular Stage policies include formulating objectives in the Sabilillah Spectacular Stage program and the timing of the program. Meanwhile, the implementation of this policy includes the policy of grouping students, the formation of the Katibah al-Mukhalifah group, Taqdim al-Mufradat, and Tadrib al-Barnamij.
\end{abstract}

Keywords: $\quad$ planning, policy, spectacular stage, speaking skills

\section{Introduction}

Viewed from its function, language is a tool or means for humans to convey what is in their minds, as well as a means of communication and social control. ${ }^{1}$ There is a huge diversity of languages in the world, one of which is Arabic. Arabic is now not only considered the language of Muslims, but also, along with the development of the times, an international language recognized by the United Nations. This happens because of the rapid development of technology and communication. ${ }^{2}$ For Muslims,

${ }^{1}$ Hasan, "Keterampilan Mengajar Bahasa Arab Materi Istima Menggunakan Media Lagu", Al Qalam: Jurnal Ilmiah Keagamaan Dan Kemasyarakatan, Vol. 15, No. 28, 2018, 127.

2 Tarmizi Ninoersy, Tabrani ZA, \& Najmul Wathan, "Manajemen Perencanaan Pembelajaran Bahasa Arab Berbasis Kurikulum 2013 Pada SMAN 1 Aceh Barat", Jurnal Kajian Ilmu-Ilmu Keislaman, Vol. 5, No. 1, 2019, 83-102. 


\section{Arabiyât Jurnal Pendidikan Bahasa Arab dan Kebahasaaraban, 8 (1), 2021}

Arabic is the language of the Qur'an, ${ }^{3}$ Allah SWT chose it as a tool to convey His word, because Arabic has many features compared to other languages. Arabic must be learned by Muslims to understand the content of the Qur'an and carry out Islamic law. ${ }^{4}$

There are four kinds of skills in the effort to master Arabic language competence which are of general concern, both for institutions and Arabic speakers. These four aspects are listening proficiency commonly referred to as maharah alistima', speaking skills or maharah al-kalam, reading skills or maharah al-qiraah, and writing skills or maharah al-kitabah. These four skills are interrelated and complementary to each other. To achieve this proficiency in Arabic, an institution or a boarding school make efforts and policies by which they train students to master the language proficiency mentioned above.

Islamic boarding schools, widely called pesantren in Indonesia, are recognized Islamic institutions that grow and develop in the local community. The pesantren provides a dormitory or a special place for its santri (students) to make it easier for them to receive religious education. In optimizing the objectives of learning Arabic, Islamic boarding schools make plans and policies to achieve one of the general goals of learning Arabic. In the context of teaching, planning is a process that aims to compile teaching materials, media, methods and assessments with specified time duration to achieve the specified goals and targets. ${ }^{5}$ In a boarding school, there is a caregiver or often known as a kyai, who is the central figure in determining and developing the boarding school he founded. A kyai must be able and clever in applying his abilities in managing his boarding school and required to be able to apply his leadership in order to advance the pesantren or the institution he founded. ${ }^{6}$

Islamic boarding schools caregivers must have a plan that includes the pesantren's planning or curriculum, planning processes, evaluations and policies to advance their pesantren. So, it can be said that the progress or decline of a pesantren is dependent on how the figure of the kyai's leadership is, how the personality of the kyai is, especially how he manages and how his expertise is in the religious field to produce qualified santri with good morality. A quality institution has a smart leader who understands the strategies and concepts that he applies in leading the institution. ${ }^{7}$ Likewise, Sabilillah Islamic boarding school is led by a kyai who guides and manages the pesantren so that this boarding school is famous for its modern Islamic boarding school with the use of two foreign languages, Arabic and English.

\footnotetext{
3 Astari, "Padanan Kosakata Arab dalam Al-Qur'an Terjemah Versi Indonesia dan Malaysia", Arabi: Journal of Arabic Studies, Vol. 5, No. 1, 2020, 63-78

${ }^{4}$ Jassem, Study on Second Language Learners of Arabic: An Error Analysis Approach, (Kuala Lumpur: Pustaka Hayathi, n.d.), 56.

${ }^{5}$ Ernawati, "Perencanaan Pembelajaran Bahasa Arab di Perguruan Tinggi Pariwisata", Arabiyat: Jurnal Pendidikan Bahasa Arab dan Kebahasaaraban, Vol. 5, No. 1, 2019, 15-37.

6 Ratih Purwasih and Arif Rahman, "Kebijakan Pimpinan Pesantren Modern Dalam Meningkatkan Kemampuan Berbahasa Asing Santri”, Tadbir, Vol. 3, No. 1, 2018, 1-17.

7 Ratih Purwasih and Arif Rahman, "Kebijakan Pimpinan Pesantren Modern Dalam Meningkatkan Kemampuan Berbahasa Asing Santri”, 1-17.
} 


\section{Arabiyât Jurnal Pendidikan Bahasa Arab dan Kebahasaaraban, 8 (1), 2021}

The Sabilillah Islamic Boarding School is an institution that teaches religious sciences and always instills religious values, discipline and independence to the students to create individuals with good qualities and morals when they return to their respective home after they are finished with their study and journey. ${ }^{8}$ In addition, this pesantren teaches not only religious subjects, but also general lessons with the aim of the students having broad insights. This pesantren teaches Arabic lessons that are focused on to improve the speaking skills (Maharah al-Kalam) students and establishes a policy with the Sabilillah Spectacular Stage program. This program is a Language Environment or commonly known as Bi'ah al-Lughah al-'Arabiyah. 'One of the factors of the success of language learning is the language environment which can shape the students according to the targeted goals. ${ }^{10}$

With the explanation above, this article aims to describe how the policies in the Sabilillah Spectacular Stage program and their implementation are to improv speaking skills (Maharah al-kalam). In this case, this article does not only discuss a policy in Arabic language learning but also its implementation. There have been a number of previous researchs on the issue of language learning planning and Arabic speaking skill. A study by Al-Issa, entitled The Language Planning Situation in The Sultanate of Oman, which aimed to find out how to plan Arabic, English, French and German in the Sultanate of Oman and how to serve the different interests and goals of students found that there are ideologies, contests, and conflicts at the LEP level which result in a lack of strategic planning and organized efforts which in turn affect language, language spread, language maintenance, and language shift. ${ }^{11}$ Another research by Yaqub, entitled Developing Speaking Skill in Arabic Learners: A Proposal for Integration of Product and Process Approaches, aimed to find out how to learn Arabic as a second language and how to motivate Arabic learners and explore issues related to Arabic speaking skills (Maharah al- Kalam) in Nigerian universities. This study used an integrative approach to Arabic pedagogy. The results of this study indicate that giving examples in Arabic speaking lessons (Maharah al-Kalam) by teachers is very effective in improving students' Arabic speaking skills. ${ }^{12}$

Awang's et al study entitled Enhancing Arabic Speaking Skills Among Malay Students Through Group Work Activities, indicated that group work activities have an important impact on Arabic speaking skills (Maharah al-kalam). Group discussions can help increase the confidence level of students who are shy, panicky and afraid to speak

${ }^{8}$ Sutarjo, "Proporsi Pengajaran Bahasa Arab Di Pondok Pesantren Ditinjau Dari Aspek Tipologi (Studi Manajemen Kurikulum Pada Pondok Pesantren di Lampung)", Jurnal An-Nabighoh, Vol. 21, No. 1, 2019, 1-19.

9 Arifatun, "Kesalahan Penerjemahan Teks Bahasa Indonesia Ke Bahasa Arab Melalui Google Translate (Studi Analisis Sintaksis)", Lisanul Arab, Journal of Arabic Learning and Teacbing, Vol. 1, No. 1, 2012, 1-6.

${ }^{10}$ Neli Putri, "Biah 'Arabiyah”, Jurnal Al-Ta'lim, Vol. 1, No. 5, 2013, 407-413.

11 A. S. al-Issa, "The language planning situation in the Sultanate of Oman", Current Issues in Language Planning, Vol. 21, No. 4, 2020, 347-414.

12 M. T. Yaqub, "Developing speaking skill in Arabic learners: A proposal for integration of product and process approaches”, European Scientific Journal, Vol. 8, No. 29, 2012. 


\section{Arabiyât Jurnal Pendidikan Bahasa Arab dan Kebahasaaraban, 8 (1), 2021}

Arabic in front of their friends. ${ }^{13}$ Meanwhile, Ratih Purwasih' study et al, ${ }^{14}$ entitled Policies of Modern Pesantren Leaders in Improving Foreign Language Skills of Students, showed that the leadership of the pesantren establishes various policies such as establishing language organizations, requiring students to use Arabic and English in every daily activity, and requiring students to participate in every activity related to improving foreign language then in its implementation using a strategy to achieve it.

Another study by Agung Setiyawan ${ }^{15}$ revealed that there are at least 7 learning problems and there are 3 package of learning program policies to overcome the differences in the educational background of the students. The difference between this study and previous studies is that this study focuses on policy and its implementation in the sabilillah spectacular stage program which aims to improve the speaking ability (Maharatul Kalam) of Arabic for the students.

\section{Method}

This research used a qualitative approach as the approach is considered more suitable with the phenomenon being studied, namely policy and its implementation in the Sabilillah Spectacular Stage program to improve maharah al-kalam students. Thus, this research is conducted in natural conditions, in other words, this research is to describe the reality of natural events that occur. This research attempted to describe phenomena and observe the behavior that occurs. The data in this study were obtained from interviews and observations and documentation. This was done by researchers to examine the data in depth and understand the problem as a whole.

The participants of the study were the boarding school caretakers (kyai), the Arabic language program coordinator, male teachers (asatidz) and female teachers (ustadzat), as well as 22 students living in the boarding school for female Islamic boarding schools and participating in the Sabilillah Spectacular Stage. The researcher limited his research to the 3rd grade students at Al-Zahra Camp, which amounted to 22 students, because the 3rd grade students at Al-Zahra Camp were the final grade students who really studied Arabic in the aspect Maharah al-Kalam. ${ }^{16}$

${ }^{13}$ N. A. Awang, M. H. Mohamed, \& R. Sulaiman, "Enhancing Arabic speaking skills among Malay students through group work activities", International Journal of Humanities and Social Science, Vol. 3 , No. 21, 2013, 212-219.

${ }^{14}$ R. Purwasih, \& A. Rahman. "Kebijakan Pimpinan Pesantren Modern dalam Meningkatkan Kemampuan Berbahasa Asing Santri”, 1-17.

15 A. Setiyawan, "Problematika Keragaman Latar Belakang Pendidikan Mahasiswa dan Kebijakan Program Pembelajaran Bahasa Arab", Arabiyat: Jurnal Pendidikan Babasa Arab dan Kebahasaaraban, Vol. 5, No. 2, 2018, 195-213.

${ }^{16}$ Burhan Bungin, Analisis Data Penelitian Kualitatif, (Jakarta: PT Raja Grafindo Persada, 2003), 70. 


\section{Arabiyât Jurnal Pendidikan Bahasa Arab dan Kebahasaaraban, 8 (1), 2021}

\section{Result and Discussion}

Policy in general can be understood as a decision made to face a certain thing. ${ }^{17}$ In other words, policy means an effort or action taken by someone to face and overcome certain problems. In essence, policy is not just a decision taken by someone to solve the problem at hand, but is an action accompanied by its application in a program or in an activity. Therefore, the benefits of policies can be seen in a concrete manner and can be observed in a plan, program or activity.

A policy will be considered a good policy if it can formulate an official statement regarding the actions that are designed and will be carried out, which is based on the existence of a theory and a deeper review of the causes and effects that will come after the policy is made and implemented. ${ }^{18}$ In this sense, policy must coexist with theory and action. ${ }^{19}$ Policies have three characteristics, namely a goal to solve a problem, a target to achieve the goals of the organization, and policies in the form of actions to solve problems.

A policyhas implications in which it leads to new policies and produce better decisions. A policy must be related to other policies, unfortunately there are policies that are not in accordance with the objectives. In general, policies are concerned with planning, making and formulating as well as implementing decisions and evaluating. The policies can be related to planning, making and formulating and implementing decisions as well as evaluating the decisions taken. In this article, the policy in question is about the Sabilillah Spectacular Stage program policy made by the caregivers of the Sabilillah Islamic boarding school which was then implemented by the Arabic language coordinator to improve the students' speaking skills (Maharah al-Kalam) of the Sabillah Islamic boarding school.

\section{Planning at the Sabilillab Islamic Boarding School}

Arabic is the language used as the language of science and communication. Arabic, apart from being an international language, has become the official language of the United Nations. In Islamic world, Arabic is the language of the Al-Qur'an, Hadith, the language of worship for Muslims and is used in writing various Islamic scientific literature $^{20}$. Therefore, studying Arabic for Muslims is absolutely essential to understand and deepen various Islamic sciences, all of which come from the AlQur'an and Hadith. The miracles and contents of the Al-Qur'an cannot be understood, penetrated and lived without knowing and understanding Arabic,

${ }^{17}$ R. Purwasih, \& A. Rahman, "Kebijakan Pimpinan Pesantren Modern dalam Meningkatkan Kemampuan Berbahasa Asing Santri”, 1-17.

18 A. Bakry, "Kebijakan pendidikan sebagai kebijakan publik", Jurnal Medtek, Vol. 2, No. 1, 2010 , $1-13$.

19 Fu’ad Arif Noor, "Analisis Kebijakan Pembelajaran Pendidikan Islam Anak Usia Dini”, Cakrawala Dini, Vol. 10, No. 1, 2019, 19-30.

${ }^{20}$ Haniah, "Analisis Kesalahan Berbahasa Arab Pada Skripsi", Arabi: Journal of Arabic Studies, Vol. 3, No. 1, 2018, 23-34. 


\section{Arabiyât Jurnal Pendidikan Bahasa Arab dan Kebahasaaraban, 8 (1), 2021}

therefore learning Arabic is absolutely necessary as the word of Allah SWT. " إنا أنزلناه " قرأنا عربيا لعلكم تعقلون Arabic is one of the languages that have touched various areas of the world. Apart from being the language of media for Islamic teachings, Arabic has also been a medium for international political. ${ }^{21}$

Planning is a series of processes to formulate a decision and contain steps or implementation of a job to achieve a goal. ${ }^{22}$ In other words, planning is the preparation of steps that will be taken to achieve a certain goal. ${ }^{23}$ Planning has several roles, namely formulating goals and procedures to achieve goals, clarifying what needs to be done in various activities in accordance with the objectives and procedures and monitoring, measuring, and evaluating the success of the activities. The Sabilillah Islamic Boarding School provides formal and non-formal education for its santri. Formal education is education that is carried out in school, such as the Madrasah Ibtidaiyyah level and equivalent, Madrasah Tsanawiyyah and the equivalent, ${ }^{24}$ and so on. This formal education usually has a defined curriculum, deadline and standardized books. Meanwhile, non-formal education is additional education that is carried out outside of school. ${ }^{25}$ In non-formal education, this the Sabilillah Islamic Boarding School has several plans regarding the pesantren curriculum. The curriculum is a plan or arrangement that contains objectives, learning materials and methods used to make guidelines. ${ }^{26}$ The The kyai of the Islamic boarding school explained that the planning of this Islamic boarding school consisted of subjects, books, methods and evaluations. This is the task of the tutor for each subject. Every teacher has an obligation to report the progress of these four things in the evaluation with the kyai.

In terms of Arabic-related subject matter, this lslamic boarding school has subjects that must be followed by students. Among them is Nabwu Science which is taught every afternoon (15:00-16:15) and evening (20:00-21:00) on Thursday and Monday, both for junior high school and high school students at all levels. While the books used are the Imrithi book for junior high school level and the Alfiyab Ibnu Malik book for high school level. Sharf knowledge is taught in the afternoon (15:00-16:15) and evening (20:00-21:00) on Friday and Saturday, both for junior high school and high school students at all levels. The book used is the Amtsilab Tashrifiyah book for both junior and senior high school levels. Arabic is taught in the afternoon (15:0016:15) and evening (20:00-21:00) on Tuesday and Wednesday, both for junior high school and high school students at all levels. While the book used is the Kalamuna

${ }^{21}$ Ahmad Muradi, “Tujuan Pembelajaran Bahasa Asing (Arab) Di Indonesia”, Jurnal Al Maqoyis, Vol. 1, No. 1, 2013, 128-137.

${ }^{22}$ M. Rosyid et al, "Manajemen Perencanaan Pembelajaran Aktif di Lembaga Kursus Bahasa Arab Al-Azhar Pare Kediri”, Lisania: Journal of Arabic Education and Literature, Vol. 3, No. 1, 2019, 1-20.

${ }^{23}$ Ramli, "Reorientasi Pengajaran Bahasa Arab", Naskbi: Jurnal Pendidikan Dan Babasa Arab, Vol. 2, No. 1, 2020, 1-7.

24 Abdul Aziz Khoiri \& Ilham Fatkhu Romadhon, " Arabic Teacher: Pembelajaran Modern Bahasa Arab Berbasis E-Learning Bagi Non-Native Speaker”, Prosiding Konferensi Nasional Bahasa Arab, Vol. 3, 2017, 290.

${ }^{25}$ Fu ad Arif Noor, “Analisis Kebijakan Pembelajaran Pendidikan Islam Anak Usia Dini”, 19-30.

${ }^{26}$ Ahmad Muradi, "Tujuan Pembelajaran Bahasa Asing (Arab) Di Indonesia”, 128-137. 


\section{Arabiyât Jurnal Pendidikan Bahasa Arab dan Kebahasaaraban, 8 (1), 2021}

which was written by Arabic language instructors at this lodge. On Sundays, this Islamic boarding school requires students to take part in the study and recitation of the Fathul Qarib and Kifayatul Akbyar fiqh books at 10:00-11:30 for both junior high and high school students at all levels.

In learning Arabic, there must be different challenges or obstacles in each institution. These obstacles are usually in the form of incomplete facilities, such as lack of learning media, lack of teacher creativity in conveying material, and students' lack of motivation in participating in learning Arabic. This can lead to unexpected impacts in learning Arabic. ${ }^{27}$ Motivation is needed in learning Arabic, because motivation has a contribution to fostering student interest in learning Arabic. ${ }^{28}$ Education is an activity of maturing children provided by family, community and government. ${ }^{29}$ In educational matters, there are several things a teacher must pay attention to so that the lessons he/she delivers are easy to understand and avoid burnout. In addition, teachers must be aware of the method, media and creativity that they have for their students. ${ }^{30}$

To improve the quality of students, an understanding of child development is needed to see if the child experiences difficulties or obstacles during the learning process. ${ }^{31}$ There are five components that support the learning process, namely: teachers, students, learning materials, media and learning objectives. However, the existence of the method also supports the learning process. In terms of method, the teachers of Nahwu and Sharf Sciences chose to use the Qawaid wa At-Tarjamah method using card media. While the Arabic language teacher uses the Mubasyarah, Sam'iyyah Syafawiyyah, and Al'ab Lughawiyyah methods.

In improving the quality of education and fixing existing problems, this pesantren often conducts evaluations held once a month. In this evaluation stage, the teachers are asked to describe the development of the students in the learning that is being taught as well as the obstacles or problems related to the education of the students.

\section{Policies in the Spectacular Stage Sabilillah Program and Its Implementation}

The objectives of the creation of an Arabic language environment are: 1) to familiarize learners with communicative use of Arabic through the practice of

${ }^{27}$ Raswan, "Model Alternatif Pembelajaran Bahasa Arab Sebagai Bahasa Al-Qur’an", Lisanul 'Arab: Journal of Arabic Learning and Teaching, Vol. 6, No. 1, 2017, 18-28.

28 Asep Muhammad Saepul Islam, "Faktor Demotivasi Pembelajaran Bahasa Arab Dalam Perspektif Siswa Madrasah", Arabiyat: Jurnal Pendidikan Babasa Arab dan Kebahasaaraban, Vol. 2, No. 1, 2015, 1-16.

${ }^{29}$ K. Andriana, "Urgensi Perencanaan Pembelajaran Bahasa Arab Dalam Pendidikan di Sekolah”, Konferensi Nasional Bahasa Arab I Universitas Negeri Malang, 2015, 195.

30 Fauziya \& Hasan Saefuloh, "Pengaruh Penggunaan Metode Sugestopedia Dalam Pembelajaran Bahasa Arab Pada Siswa Kelas XII SMA Negeri 1 Jamblang”, Jurnal El-Ibtikar, Vol. 7, No. 1, 2017, 59-77.

${ }^{31}$ Sa'dah, "Pelaksanaan Outdoor Study dalam Pembelajaran Bahasa Arab di SMA Ma'arif NU 1 Kemranjen Banyumas", Thesis, Fakultas Tarbiyah dan Ilmu Keguruan IAIN Purwokerto, 2015. 


\section{Arabiyât Jurnal Pendidikan Bahasa Arab dan Kebahasaaraban, 8 (1), 2021}

conversations, discussions, seminars, lectures and expression through writing, 2) to provide reinforcement in the acquisition of Arabic which has been learned in the classroom, and 3) to foster creativity and Arabic language activities which integrated between theory and practice in a pleasant informal atmosphere. In short, the goal of creating an Arabic language environment is to improve the abilities and skills of students, lecturers and others in active Arabic, both spoken and written, so that the Arabic language learning process becomes more dynamic, effective and meaningful.

Learning Arabic with its various characteristics and motivation to learn it among non-Arabic people still face many obstacles and problems because Arabic is still not an easy language to be totally mastered. The problems that usually arise in learning Arabic for non-Arabs are divided into two problems, linguistic and nonlinguistic problems. One of the factors that determine and influence the success of the learning process is the environment (enviromnet), including Arabic. The existence of an Arabic language environment is very important because it is always present, encompassing, providing the nuances and context of the learning itself. If the environment in which Arabic learning is conducive, the learning process will also be conducive.

Sabilillah Islamic Boarding School in teaching Arabic has a biah lughawiyyah with the name Sabilillah Spectacular Stage. This program has a policy. The policy in the Sabilillah Spectacular Stage is to formulate the objectives and timing of the Sabilillah Spectacular Stage. Meanwhile, the implementation is in the form of santri grouping, the formation of the group Katibah al-mukhalifah, taqdim al-mufradat, and tadrib al-barnamij. Sabililillah Spectacular Stage is an activity that refers to the language environment. The environment is one of the natural learning places for humans, one can learn many things through the environment, including language. ${ }^{32}$ Likewise with Arabic, it can be learned from an environment that usually uses Arabic, or what is commonly called $B i^{\prime} a b$ Arabiyah, ${ }^{33} B i^{\prime} a b$ Arabiyah is a place to interact and communicate using Arabic. ${ }^{34}$ Bi'ah Arabiyah neglecting ateaches can be formed by policy issued by a leader or teacher who Arabic language learning. objective of Among the Bi'ah Arabiyah is to create a habit of communicating with Arabic, either orally or in writing.

The first policy of the Sabililillah Spectacular Stage is to formulate goals. The head coordinator of the Sabililillah Spectacular Stage program explained when interviewed on 23-12-2020, that the aim of the Sabililillah Spectacular Stage program was to improve the mastery of the maharatul kalam students of Sabilillah. Maharah alKalam is the goal because in Maharah al-Kalam, students are expected to be able to convey ideas, thoughts and feelings through oral communication properly and

${ }^{32}$ Muhammad Rizal Rizqi, "Resonansi Bi'ah Lughawiyyah Dalam Meningkatkan Akuisisi Bahasa Arab”, Dar el-Ilmi, Vol. 4, No. 2, 2017, 89-105.

33 A. Hidayat, "Bi'ah lughawiyah”, Jurnal Pemikiran Islam, Vol. 37, No. 1, 2012, 35-44.

${ }^{34}$ Neli Putri, "Biah 'Arabiyah", 407-413. 


\section{Arabiyât Jurnal Pendidikan Bahasa Arab dan Kebahasaaraban, 8 (1), 2021}

correctly. ${ }^{35}$ This Islamic boarding school wants to produce students by becoming individuals who excel in the knowledge of Arabic and can communicate and convey the ideas of their students by using Arabic. The second policy is about the timing of the Sabilillah Spectacular Stage. The head coordinator of the Sabililillah Spectacular Stage program explained when interviewed on 23-12-2020, that the Sabilillah Spectacular Stage program implementation time was placed on Sunday afternoons from 15:00-16:30. Sunday was chosen because Sunday afternoon is a quiet day for the students in this cottage.

Policy implementation is important to know the its effectiveness in practical level. ${ }^{36}$ The first policy implementation of the Sabililillah Spectacular Stage program was a grouping of students. In this case, the researcher limited the Sabilillah santri to Azzahra Camp which consisted of 22 students. The santri grouping is very necessary to determine the development of the Maharah al-Kalam santri. Based on the observations, the Azzahra Camp students were grouped into 3 classes. The mubtadi class with 5 people, the mutawassith class with 5 people and the mutaqaddim class with 7 people. The mubtadi class is a class specifically for students who are not very fluent in communicating Arabic. This class textbook is the Kalamuna 1 juz 1, 2 and 3. The kalamuna book 1 contains the mufradat and the number of mufidah. Meanwhile, the mutawassith class is a class specifically for students who are fluent in communicating with the Arabic language. They used the book Kalamuna 2 juz 1, 2, 3, containing mahfudzat as well as some exercises in the mastery of Maharah al-Kalam. The mutaqaddim class is a special class for students that are printed to develop Maharah al-Kalam. The book used is Kalamuna 3, this book contains the themes of Mujadalah, Munadharah, and Munaqasyah which students must prepare per week.

The implementation of the second Sabilillah Spectacular Stage program policy is the formation of thegroup Katibah al-Mukhalifah. This group is tasked with recording students who do not use Arabic when communicating with fellow Sabililillah students. The group Katibah al-Mukhalifah is students in the mutaqaddim class, they are tasked to take notes and give sanctions for students who violate the language rules. While the implementation of the third Sabilillah Spectacular Stage program policy is the Taqdim al-Mufradat, speaking proficiency can be achieved not only by memorizing Mufradat, answering questions, answering exercises, compiling sentences into the number of jumlah mufidah in writing books and so on. However, in this case it is necessary to practice speaking directly. ${ }^{37}$ Mufradat in Indonesian is called vocabulary, a collection of words which are later arranged into a sentence that can be understood the meaning. ${ }^{38}$

${ }^{35}$ H. Nur, "Penerapan Metode Muhadatsah Dalam Meningkatkan Hasil Belajar Maharah Kalam Peserta Didik", Lentera Pendidikan: Jumal Ilmu Tarbiyah dan Keguruan, Vol. 20, No. 2, 2017, 177-187

${ }^{36}$ Nurharjadmo \& Negara, "Evaluasi Implementasi Kebijakan Pendidikan", Jurnal Spirit Publik, Vol. 4, No. 2, 2008, 215-228.

37 Nuril Mufidah, "Pengajaran Kosa Kata Untuk Mahasiswa Kelas Intensif Bahasa Arab", Uniqbu Journal of Social Sciences, Vol. 1, No. 1, 2020, 1-9.

38 Ahmad Izzan, Metodologi Pembelajaran Bahasa Arab, Cet. II, (Bandung: Humaniora, 2007), 33. 


\section{Arabiyât Jurnal Pendidikan Bahasa Arab dan Kebahasaaraban, 8 (1), 2021}

mastery of mufradat is vital to master Arabic speaking skills. ${ }^{39}$ Meanwhile, the implementation of the last Sabilillah Spectacular Stage program policy is Tadrib alBarnamij or pre-performance training. In this case, the mutaqaddim class assignment is to evaluate and provide an assessment for other classes before the day of the performance. Assessment has an important role and has many benefits for the progress of students. ${ }^{40}$ The pre-stage training is held on Friday afternoon from 14: 3016:45. After this tadrib al-barnamij has been done and has been repaired, then this activity will be staged on Sunday afternoons at the Sabilillah Spectacular Stage program.

\section{Conclusion}

The existence of Bi'ah lughawiyyah is very important to acquire Arabic language skills because it has an important influence and role. Bi'ah lughawiyyah can encourage and motivate students to develop Arabic and apply it in daily communication. Bi'ah lughawiyyah must have adequate facilities and infrastructure to improve speaking skills (Maharah al-Kalam). The program should have planning and policies. This qualitative study focuses on policy and its implementation in the Sabilillah Spectacular Stage program which aims to improve the Maharah al-Kalam. Meanwhile, the implementation of this policy includes the policy of grouping students into 3 levels, namely: beginner (mubtadi'), intermediate (wushtha), and advanced ('ula), the formation of the Katibah alMukhalifah group to oversee the foreign language of students in their respective rooms, Taqdim al-Mufradat at morning, and Tadrib al-Barnamij which is evaluated by students at the 'ula level. Planning and policies are very important in the success of the learning process. The essence of planning and policy is its implementation, the implementation of these two things must be different between Bi'ah lughawiyyah in one place and another; thus it should be developed over time.[]

\section{REFERENCES}

Andriana, K. "Urgensi Perencanaan Pembelajaran Bahasa Arab Dalam Pendidikan di Sekolah", Konferensi Nasional Bahasa Arab I Universitas Negeri Malang, 2015.

Arifatun, Novia. "Kesalahan Penerjemahan Teks Bahasa Indonesia Ke Bahasa Arab Melalui Google Translate (Studi Analisis Sintaksis)", Lisanul Arab, Journal of Arabic Learning and Teaching, Vol. 1, No. 1, 2012.

Astari, R., A. Malik, N. D. Putrisari, \& U. Dahlan. "Padanan Kosakata Arab dalam AlQur'an Terjemah Versi Indonesia dan Malaysia", Arabi: Journal of Arabic Studies, Vol. 5, No. 1, 2020.

39 M. Hendri, "Pembelajaran Keterampilan Berbicara Bahasa Arab Melalui Pendekatan Komunkatif”, Potensia: Jurnal Kependidikan Islam, Vol. 3, No. 2, 2017, 196.

${ }^{40}$ Nuril Mufidah, "Pengajaran Kosa Kata Untuk Mahasiswa Kelas Intensif Bahasa Arab”, 1-9 


\section{Arabiyât Jurnal Pendidikan Bahasa Arab dan Kebahasaaraban, 8 (1), 2021}

Awang, N. A., M. H. Mohamed, \& R. Sulaiman. "Enhancing Arabic speaking skills among Malay students through group work activities", International Journal of Humanities and Social Science, Vol. 3, No. 21, 2013.

Bakry, A. "Kebijakan pendidikan sebagai kebijakan publik", Jurnal Medtek, Vol. 2, No. $1,2010$.

Noor, Fu’ad Arif. "Analisis Kebijakan Pembelajaran Pendidikan Islam Anak Usia Dini”, Cakrawala Dini, Vol. 10, No. 1, 2019.

Ernawati. "Perencanaan Pembelajaran Bahasa Arab di Perguruan Tinggi Pariwisata", Arabiyat: Jurnal Pendidikan Bahasa Arab dan Kebahasaaraban, Vol. 5, No. 1, 2019.

Fauziya., \& Hasan Saefuloh. "Pengaruh Penggunaan Metode Sugestopedia Dalam Pembelajaran Bahasa Arab Pada Siswa Kelas XII SMA Negeri 1 Jamblang”, Jurnal El-Ibtikar, Vol. 7, No. 1, 2017

Hasan. "Keterampilan Mengajar Bahasa Arab Materi Istima Menggunakan Media Lagu", Al Qalam: Jurnal Ilmiah Keagamaan Dan Kemasyarakatan, Vol. 15, No. 28, 2018.

Hendri, M. "Pembelajaran Keterampilan Berbicara Bahasa Arab Melalui Pendekatan Komunkatif', Potensia: Jurnal Kependidikan Islam, Vol. 3, No. 2, 2017.

Hidayat, Ahmad. "Bi’ah lughawiyah”, Jurnal Pemikiran Islam, Vol. 37, No. 1, 2012.

Nuril Mufidah. "Pengajaran Kosa Kata Untuk Mahasiswa Kelas Intensif Bahasa Arab”, Uniqbu Journal of Social Sciences, Vol. 1, No. 1, 2020.

Islam, Asep Muhammad Saepul. "Faktor Demotivasi Pembelajaran Bahasa Arab Dalam Perspektif Siswa Madrasah", Arabiyat: Jurnal Pendidikan Bahasa Arab dan Kebahasaaraban, Vol. 2, No. 1, 2015.

al-Issa, A. S. "The language planning situation in the Sultanate of Oman", Current Issues in Language Planning, Vol. 21, No. 4, 2020.

Izzan, Ahmad. Metodologi Pembelajaran Bahasa Arab. Bandung: Humaniora, 2007.

Jassem, Ali Jassem. Study on Second Language Learners of Arabic: An Error Analysis Approach. Kuala Lumpur: Pustaka Hayathi, 2000.

Khoiri, Abdul Aziz., \& Ilham Fatkhu Romadhon. "Arabic Teacher: Pembelajaran Modern Bahasa Arab Berbasis E-Learning Bagi Non-Native Speaker", Prosiding Konferensi Nasional Bahasa Arab, Vol. 3, 2017.

Muradi, A. "Tujuan Pembelajaran Bahasa Asing (Arab) Di Indonesia", Jurnal Al Maqoyis, Vol. 1, No. 1, 2013.

Ninoersy, Tarmizi., Tabrani ZA, \& Najmul Wathan. "Manajemen Perencanaan Pembelajaran Bahasa Arab Berbasis Kurikulum 2013 Pada SMAN 1 Aceh Barat", Jurnal Kajian Ilmu-Ilmu Keislaman, Vol. 5, No. 1, 2019. 


\section{Arabiyât Jurnal Pendidikan Bahasa Arab dan Kebahasaaraban, 8 (1), 2021}

Nur, H. "Penerapan Metode Muhadatsah Dalam Meningkatkan Hasil Belajar Maharah Kalam Peserta Didik", Lentera Pendidikan: Jurnal Ilmu Tarbiyah dan Keguruan, Vol. 20, No. 2, 2017.

Nurharjadmo, W., \& J. A. Negara. "Evaluasi Implementasi Kebijakan Pendidikan”, Jurnal Spirit Publik, Vol. 4, No. 2, 2008.

Purwasih, R., \& A. Rahman. "Kebijakan Pimpinan Pesantren Modern Dalam Meningkatkan Kemampuan Berbahasa Asing Santri", Tadbir, Vol. 3, No. 1, 2018.

Putri, Neli. "Biah 'Arabiyah", Jurnal Al-Ta'lim, Vol. 1, No. 5, 2013.

Ramli. "Reorientasi Pengajaran Bahasa Arab", Naskbi: Jurnal Pendidikan Dan Bahasa Arab, Vol. 2, No. 1, 2020.

Raswan. "Model Alternatif Pembelajaran Bahasa Arab Sebagai Bahasa Al-Qur'an", Lisanul 'Arab: Journal of Arabic Learning and Teaching, Vol. 6, No. 1, 2017.

Rizqi, Muhammad Rizal. "Resonansi Bi'ah Lughawiyyah Dalam Meningkatkan Akuisisi Bahasa Arab", Dar el-Ilmi, Vol. 4, No. 2, 2017.

Rosyid, M. K., Faizin, M. S., Nuha, N. U., \& Arifa, Z. "Manajemen Perencanaan Pembelajaran Aktif di Lembaga Kursus Bahasa Arab Al-Azhar Pare Kediri”, Lisania: Journal of Arabic Education and Literature, Vol. 3, No. 1, 2019.

Sa'dah, Zulfa. "Pelaksanaan Outdoor Study dalam Pembelajaran Bahasa Arab di SMA Ma'arif NU 1 Kemranjen Banyumas", Thesis, Fakultas Tarbiyah dan Ilmu Keguruan IAIN Purwokerto, 2015.

Setiyawan, A. "Problematika Keragaman Latar Belakang Pendidikan Mahasiswa dan Kebijakan Program Pembelajaran Bahasa Arab", Arabiyat: Jurnal Pendidikan Bahasa Arab dan Kebahasaaraban, Vol. 5, No. 2, 2018.

Sutarjo, Albarra Sarbaini. "Proporsi Pengajaran Bahasa Arab Di Pondok Pesantren Ditinjau Dari Aspek Tipologi (Studi Manajemen Kurikulum Pada Pondok Pesantren di Lampung)", Jurnal An-Nabighoh, Vol. 21, No. 1, 2019

Yaqub, M. T. "Developing speaking skill in Arabic learners: A proposal for integration of product and process approaches", European Scientific Journal, Vol. 8, No. 29, 2012. 